\section{THE RELATION BETWEEN \\ TEACHERS' ATTITUDES \\ TOWARDS RENEWABLE ENERGY \\ SDURCES AND CRITICAL \\ THINKING DISPOSITIONS}

\section{Gokhan Guven, Nevin Kozcu Cakir}

\section{Introduction}

One of the most important requirements for sustaining human life is energy because life is an energy cycle, and energy is used in every activity and at every moment of daily life. However, the consumption of energy sources, which has increased by the industrialization, the amount of consumed energy and the need for it are increasing rapidly due to the increase in production technologies and population (Karakas, 2014). In order to meet this need, countries are using different energy sources. For this reason, while determining energy policies, they aim to use energy sources that minimize environmental problems as well as meeting the energy needs in the best way. Among energy production sources, solar, wind, hydraulic, biomass, geothermal, tidal and energy derived from waves are renewable, while the energy obtained from nuclear, petroleum, coal and natural gas is classified as non-renewable energy sources (Liarakou, Gavrilakis, \& Flouri, 2009).

In order to meet their energy needs, countries prefer fossil fuels such as coal and oil, due to the developments in the production technologies and the cheapness of these sources. However, the combustion of these fuels causes the concentration of greenhouse gases such as $\mathrm{CO}_{2^{\prime}} \mathrm{CH}_{4^{\prime}} \mathrm{CFCs}$, halons, $\mathrm{N}_{2^{\prime}}$ ozone and peroxy acetylnitrate to increase in the atmosphere and the surface temperature of the earth to rise. Many environmental problems such as global warming, acid rain, climate change, disasters and migrations emerge as a result of increase and retention of heat spreading from the surface of the Earth (Dincer, 1998; Koroneos, Spachos, \& Moussiopoulos, 2003). The emergence of such problems and the fact that fossil fuel reserves are limited and exhaustible raise the importance of renewable energy sources.

\section{Renewable Energy Sources}

Renewable energy is defined as the energy source that can exist in a short time within the evolution of nature itself. These sources have an important place for the world and our country since they are renewable, have minimum impact on environment, their operating and maintenance costs are low, they are national and supply reliable energy (Haskok, 2005). The use

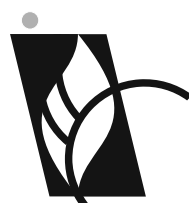

J O U R N A L

$\mathrm{OF} \bullet \mathrm{B}$ A L T I C

$S$ C I E N C E

E DUCATION

ISSN 1648-3898 /Print/ ISSN 2538-7138 /Online/

Abstract. In this research, it was aimed to explore the relation between attitude towards renewable energy sources and critical thinking disposition. For this purpose, relational survey model was used in the research. The research group consisted of 468 prospective teachers studying in faculty of education in a public university in the fall semester of 2018-2019 academic year. Renewable Energy Sources Attitude Scale in order to evaluate prospective teachers' attitudes towards renewable energy sources, and Critical Thinking Disposition Scale for evaluating critical thinking dispositions were used. In the research, the relation between the data set for attitude towards renewable energy sources comprising of variables which are application request, importance of education, country interest, environmental awareness and investments and the data set for critical thinking disposition comprising of variables which are metacognition, flexibility, systematicity, tenacity-patience, open-mindedness by the canonical analysis. As a result of the canonical correlation analysis, a significant relation was found between the attitudes towards renewable energy sources and the critical thinking dispositions and it was found that the common variance shared between the data sets was $22.23 \%$.

Keywords: renewable energy, critical thinking disposition, prospective teachers, relational survey model.

Gokhan Guven, Nevin Kozcu Cakir Mugla Sitki Kocman University, Turkey 
of clean and renewable energy sources becomes inevitable considering the extinction of natural resources, global warming, climate change, the increase in greenhouse gases and energy demand, the possibility of exhaustion of fossil fuels and uncertainty in oil prices (Apergis \& Payne, 2010; Komor \& Bazilian, 2005; Sarac \& Bedir, 2014). The use of renewable energy sources may reduce the carbon footprint resulting from the use of global energy. If the share of renewable energy is doubled by 2030 , the emission release can be reduced by approximately half. In addition, when combined with energy efficiency, the average rise in global temperature can be kept below $2^{\circ} \mathrm{C}\left(1.5^{\circ} \mathrm{C}\right)$ and climate change can be avoided before being a global disaster (Bayrac, 2010; Dogan, 2014). For this reason, European countries aim to supply $20 \%$ of the energy from renewable energy sources by 2020 while USA aims $30 \%$ of the energy by 2030 (Balocco \& Grazzini, 2007). However, when examining production of electric energy in Turkey in 2018, it appears that approximately $71 \%$ of the electrical energy has been produced from fossil fuel sources, and $29 \%$ of it from renewable energy sources. Also, Turkey is dependent on foreign countries because of the limited non-renewable energy sources. Even the dependence on foreign source for oil (90\%) and natural gas (95\%) is quite high (Guner \& Turan, 2017). However, it can be said that it is a country that has rich regions in terms of renewable energy resources and its geographical location makes the use of these resources possible (Baris \& Kucukali, 2012; Benli, 2013; Yuksel \& Kaygusuz, 2011). In this context, among the most potential and the most used renewable energy sources, the solar, hydraulic and wind are in the lead in Turkey (Cebesoy \& Karisan, 2017). However, although 600 geothermal resources have been identified in Turkey, whose temperatures reach until $100^{\circ} \mathrm{C}$, the biomass obtained from potential urban waste and the geothermal energy cannot be utilized sufficiently. In this respect, it is important to ensure that sustainable and renewable energy resources are used widely and effectively in order to reduce environmental pollution, to eliminate environmental problems such as global warming and climate change and to leave a healthy world to future generations (Karabulut \& Alkan, 2010).

Education plays an important role in demonstrating positive attitudes and behaviour tendencies in individuals who use renewable energy sources (Liarakou et.al., 2009). If individuals can have a positive attitude towards renewable energy resources by education, it can be ensured that individuals refer alternative energy sources, use resources consciously, get the idea of protecting the environment and develop awareness of responsibility towards the environment (Koca \& Bulut, 2015). It seems that the society has negative attitudes and behaviours towards the use of renewable energy (Krohn \& Damborg, 1999; Liarakou, et al., 2009; Wolsing, 2007). In addition, in the literature, in the researches regarding the renewable energy sources, primary and secondary school students (Coker, Catlioglu, \& Birgin, 2010; Kilinc, Stanisstreet, \& Boyes, 2009), high school students (Halder, Pietarinen, Nuutinen, \& Pelkonen, 2010; Yuenyong, Jones, \& Yutakom, 2008; Zyadin, Puhakka, Ahponen, Cronberg \& Pelkonen, 2012) and prospective teachers (Bilen, Ozel \& Surucu, 2013; Celikler, 2013; Firat, Sepetcioglu, \& Kiraz, 2012; Guven \& Sulun, 2017; Karatepe, Varbak, Kecebas, \& Yumurtaci, 2012; Zyadin, et.al., 2012) have been found to have negative attitudes.

In this context, to form environmental awareness, values, attitudes, skills and behaviours, which is necessary for sustainable development, is possible only by training programs and equipped teachers (Guven \& Sulun, 2017). Celikler (2013) also emphasized that important teachers have important duties to create awareness in students who have negative attitudes towards renewable energy. Teachers who have positive attitudes towards these resources will help students learn and realize the benefits of renewable energy for society and the environment, and look out for the interests of the country regarding energy policies (Halder, Nuutinen, Pietarinen, \& Pelkonen, 2011; Liarakou, et.al., 2008). Considering this situation, it is necessary to educate teachers who have positive attitudes towards renewable energy in order to raise individuals who question global environmental problems, search their effects and causes and conduct ideas in this direction, do not harm the environment and are interested in and develop positive attitudes towards the use of renewable energy sources. However, first of all, it is necessary to search for the reasons why prospective teachers have negative attitudes towards renewable energy sources. When the researches in this regard have been reviewed, the studies have reported that whether individuals have a critical thinking disposition can affect their thoughts, evaluations, decisions and attitudes towards renewable energy sources (Lee, 2016; Opitz, 2016; Sakschewski, Eggert, Schneider, \& Bogeholz, 2014). In this respect, it has been thought that there may be a relationship between prospective teachers' attitudes towards renewable energy sources and their critical thinking dispositions.

\section{Critical Thinking}

The main objective of 21 st century education is to raise individuals who are capable of meeting the demands of the current age, adapt to their living standards, follow the technology, think critically and solve problems, are creative, have communication power and who are open to cooperation. Among these competencies critical 
thinking is in the lead (Colwill \& Gallagher, 2007). Critical thinking is a process with universal values based on the intuition, logic and experience used by the individuals in case of challenges during their lives (Tasci, 2005). This process starts with analysis, continues with interpretation, self-regulation, inference and explanation, followed by evaluation (Craft, 2003; Rudd, 2007).

Critical thinking is addressed in two basic dimensions. These are critical thinking skills and critical thinking dispositions (Ozdemir, 2005; Walsh \& Hardy, 1999). Critical thinking skill means that a person can think in a critical way easily and ably with a mental effort, whereas tendency means a person's desire for critical thinking (Zhang, 2003). Tendencies are related to attitudes in human nature and develop over time, influenced by factors such as peer, environmental factors. Tendencies are powerful markers of critical thinking and, they are changeable, but this change occurs slowly over time. Individuals with a low level of tendency for critical thinking do not address complex problems, not seek different solutions to problems, not question judgments or not try to solve problems (Irani, Rudd, Gallo, Ricketts, Friedel, \& Rhoades, 2007). Moreover, individuals who do not have a critical thinking disposition do not use these skills even if they have critical thinking skills. In contrast to this, individuals with these tendencies are more enthusiastic for critical thinking. Therefore, the development of tendencies, which are paths for critical thinking, is one of the main requirements for the individual to think critically (Tishman, Jay, \& Perkins, 1993). An individual with a critical thinking disposition has qualifications such as using reliable sources for a problem, searching for reasons and options, being open-minded, taking or changing stance in cases where the evidence and reasons are sufficient, searching for certainty, looking holistically at complex issues and handling the parts of a whole in an organized way, being sensitive to others' feelings, knowledge and culture levels (Ennis, 1985).

Instead of raising individuals who accept the given information without questioning, in the contemporary education concept, it is aimed to educate individuals who know what, why and how to learn, who use the knowledge they learn, develop and produce new knowledge (Senlik, Balkan, \& Aycan, 2011) because critical thinkers are open to new ideas, question the causes of a problem, reach reliable sources, try to determine the main point without being obsessed with details, respect others' opinions, pay regard to others, form their own views on a scientific basis. In addition, critical thinking allows individuals to see incidents as multidimensional rather than one dimensional (Girot, 2000). In this context, it can be said that critical thinking is an integral part of education (Norris, 1985). However, if the content and methods in the teaching process are formed in such a way as to provide skills such as critical, creative and scientific thinking and reasoning, students will be able to think critically in a higher level (Emir, 2012). Thus, when students' critical thinking skills are included regularly in classes, students' level of critical thinking will increase (Besoluk \& Onder, 2010). The teacher who adopts critical thinking will contribute to the cognitive development of his/her students and will increase their positive attitudes towards critical thinking (Seferoglu \& Akbiyik, 2006). Given this situation the prospective teachers should have a tendency to think critically (Erdem, Ilgan, \& Celik, 2013; Tas, 2004; Yanpar-Yelken, 2009). However, when the literature is reviewed, it is seen that the teachers' critical thinking dispositions are low or moderate (Akar, 2007; Alper, 2010; Argon \& Selvi, 2011; Ay, Padem, \& Eris, 2010; Besoluk \& Onder, 2010; Can \& Kaymakci, 2015; Cekic, 2007; Cetin, 2008; Dayioglu, 2003; Gulveren, 2007; Guven \& Kurum, 2008; Jatmiko, Prahani, Supardi, Wicaksono, Erlina, Pandiangan, \& Althaf, 2018; Kocak, Kurtlu, Ulas, \& Epcacan, 2015; Korkmaz, 2009a; 2009b; Kokdemir, 2003; Kurum, 2002; Ozdemir, 2005; Sacli \& Demirhan, 2008; Sen, 2009; Turnuklu \& Yesildere, 2005; Yaman \& Yalcin, 2005; Zayif, 2008). In this context, considering the studies which have been reviewed, it can be said that the critical thinking dispositions of the prospective teachers in our country are not sufficient.

\section{Problem of Research}

In summary, it is necessary to raise individuals and students who question global environmental problems, search their effects and causes and conduct ideas in this direction, who are interested in and develop attitudes towards the use of renewable energy sources that do not harm the environment. In addition, these individuals and students should make inquiries about the problems, know what, why and how to learn, and they should tend to think critically by generating new information. However, it is seen that both the attitudes of our prospective teachers towards renewable energy sources and their critical thinking dispositions are not sufficient. Researches in this regard also emphasize that thoughts, interests, evaluations, decisions and attitudes towards renewable energy sources can be influenced by critical thinking dispositions of individuals (Lee, 2016; Opitz, 2016; Sakschewski et.al., 2014). From this point of view, in the research, it is aimed to examine the relation between prospective teachers' attitudes towards renewable energy sources and their critical thinking dispositions. 


\section{Research Methodology}

\section{Research Model}

In this research, relational survey model, which is a pattern of the survey model, was used. The survey model is used to describe a past or present event or situation (Islamoglu, 2003). In the relational (correlational) pattern, which is a type of survey model, it is tried to determine the presence and/or degree of the interchange between two or more variables (Fraenkel, \& Wallen, 2006; Karasar, 2016). The research group consists of the teachers who research in the faculty of education in the Mugla Sitki Kocman University in the fall semester of 2018-2019 academic year.

\section{Study Group}

In this research, convenient case sampling method was used, which is one of the purposive samplings. The research group included a total of 468 prospective teachers comprising of 155 individuals from the department of early childhood education, 106 from the department of social sciences teaching, 94 from the department of science teaching and 113 from the department of elementary teaching in the Mugla Sitki Kocman University. In this case, according to the $95 \%$ confidence interval, it is seen that the sample size is sufficient to reduce sampling error (Yazicioglu \& Erdogan, 2014).

Of the research group, $324(69.2 \%)$ were female and $144(30.8 \%)$ were male prospective teachers. The distribution of the class level where the data was collected is; 1 st grade $n=156(33.3 \%)$, 2nd grade $n=120(25.6 \%)$, 3rd grade $n=51(10.9 \%)$, 4th grade $n=141(30.1 \%)$. Stevens (2009) stated that the reliability of the findings in the canonical correlation analysis can be achieved by 20 times more participants than the sum of the variables in each set. When the scales used in this study are examined, there are 9 variables in total, 4 of which are application request, importance of education, country interest, environmental awareness and investments in the data set of Renewable Energy Sources Attitude Scale; and 5 of which are metacognition, flexibility, systematicity, tenacity-patience and open-mindedness in the data set of Critical Thinking Disposition Scale. For the reliability of the findings, there must be at least 180 participants $(9 \times 20=180)$ since there should be 20 times more participants than the total number of variables. Considering the number of the sample group, it can be said that there are sufficient participants for the reliability of the findings. Additionally, ethical issues were addressed. Thus, the required permission was obtained from the university ethics commission, and the participants filled the consent forms.

\section{Instrument and Procedures}

Renewable Energy Sources Attitude Scale: Gunes, Alat and Gozum (2013) developed the Renewable Energy Sources Attitude Scale, which has 4 sub-dimensions; application request (9 items), importance of education ( 6 items), country interest ( 6 items), environmental awareness and investments (5 items). The scale consists of 26 items in 5-point Likert-type, 13 of which are positive and 13 of which are negative. The overall Cronbach's Alpha reliability coefficient value of the scale was .87; in this research, Cronbach's Alpha reliability coefficient was calculated as .91. Cronbach's Alpha reliability coefficients calculated in line with the sample items belonging to sub-dimensions and reliability study are shown in Table 1.

Table 1. Reliability coefficients of Renewable Energy Sources Attitude Scale sub-scales with sample items.

\begin{tabular}{lccl}
\hline Sub-scale & $\begin{array}{c}\text { Cronbach's Alpha } \\
\text { (Original Scale) }\end{array}$ & $\begin{array}{c}\text { Cronbach's Alpha } \\
\text { (This Scale) }\end{array}$ & \multicolumn{1}{c}{ Sub-Item } \\
\hline Application Request (AR) & .97 & .76 & $\begin{array}{l}\text { I would like to attend scientific meetings on } \\
\text { renewable energy resources. } \\
\text { Importance of Education (IE) }\end{array}$ \\
Country Interest (Cl) & .80 & .66 & $\begin{array}{l}\text { I think education is an important tool to use } \\
\text { renewable energy correctly and effectively. }\end{array}$ \\
Environmental Awareness and Investments (EAl) & .78 & .72 & $\begin{array}{l}\text { I do not think that converting renewable energy } \\
\text { sources into energy will help development. } \\
\text { The use of renewable energy sources does not } \\
\text { protect environment. }\end{array}$ \\
\hline
\end{tabular}


Critical Thinking Disposition Scale [CTHD]: It used in the research was developed by Semerci (2016). The scale consists of 49 items and 5-point Likert type. The scale has five sub-dimensions: metacognition ( 14 items), flexibility (11 items), systematicity (13 items), tenacity-patience ( 8 items), open-mindedness ( 3 items). The overall Cronbach's Alpha reliability coefficient value of the scale was .96; in this study, Cronbach's Alpha reliability coefficient was calculated as .95. Cronbach's Alpha reliability coefficients calculated in line with the items belonging to sub-dimensions and reliability study are shown in Table 2.

Table 2. Reliability coefficients of the Critical Thinking Disposition sub-scales with sample items.

\begin{tabular}{lccc}
\hline \multicolumn{1}{c}{ Sub-scales } & $\begin{array}{c}\text { Cronbach's Alpha } \\
\text { (Original Scale) }\end{array}$ & $\begin{array}{c}\text { Cronbach's Alpha } \\
\text { (This Scale) }\end{array}$ & Sub-Item \\
\hline Metacognition (MC) & .90 & .87 & If there is something which I am bad at, I try to fix it. \\
Flexibility (FX) & .89 & .86 & I can suggest more than one solution to solve a problem. \\
Systematicity (SYS) & .90 & .87 & When I read any article, I can quickly find the main idea. \\
Tenacity-Patience (TP) & .84 & .83 & I usually do what I do in a perfect and complete way. \\
Open-Mindedness (OM) & .67 & .63 & I collect enough data before I decide. \\
\hline
\end{tabular}

Data Analysis

The relation between prospective teachers' attitudes towards renewable energy sources and their critical thinking disposition was searched by canonical correlation analysis. Canonical correlation examines the directional relation between a $X$ variable group $(X 1, X 2, \ldots X p)$ and a $Y$ variable group $(Y 1, Y 2, Y 3, \ldots Y n)(L i, 2012)$. However, the variable groups $X$ and $Y$ should be 2 or more than 2 in their own group. The reason why canonical correlation analysis is preferred instead of multiple regression in the study is that in multiple regression analysis, the relation between a single variable $(Y)$ and two or more variables $(X 1, X 2, \ldots X p)$ (Cohen, 1968), while the canonical correlation allows simultaneously examination of the connection of multiple numbers of $Y$ variable with a large number of X-variable and includes structural equation models (Bordens \& Abbott, 2011; Henson, 2002; Knapp, 1978). The most important feature of the canonical analysis is that the relation between two datasets can be demonstrated by a single analysis and allows to keep the Type I error in minimum in the measurement process (Sherry \& Henson, 2005; Thompson, 1991).

When the data set variables used in the research are examined; in the dimension of the attitude towards renewable energy sources there are 4 variables; application request, importance of education, country interest, environmental awareness and investments; and in the dimension of critical thinking disposition; metacognition, flexibility, systematicity, tenacity-patience, open-mindedness; that is, 9 variables in total. The data sets formed here were called set 1 and set 2 and the relation between two data sets was determined without taking as dependent and independent variables (Stevens, 2012).

Before the canonical correlation analysis, it was searched whether the data showed normal distribution. Skewness and Kurtosis values were examined for normality test. It was seen that the value of Kurtosis was between - 657 and +1.5 , and the Skewness value changed between -.613 and +.337 . According to Tabachnick and Fidell (2007), the Skewness and Kurtosis values were between -1.5 and +1.5 , indicating a normal distribution of data. The canonical correlation analysis was performed with SPSS 20 program in the significance level of .05 and by syntax writing. A general diagram of the canonical correlation analysis is shown in Figure 1. 


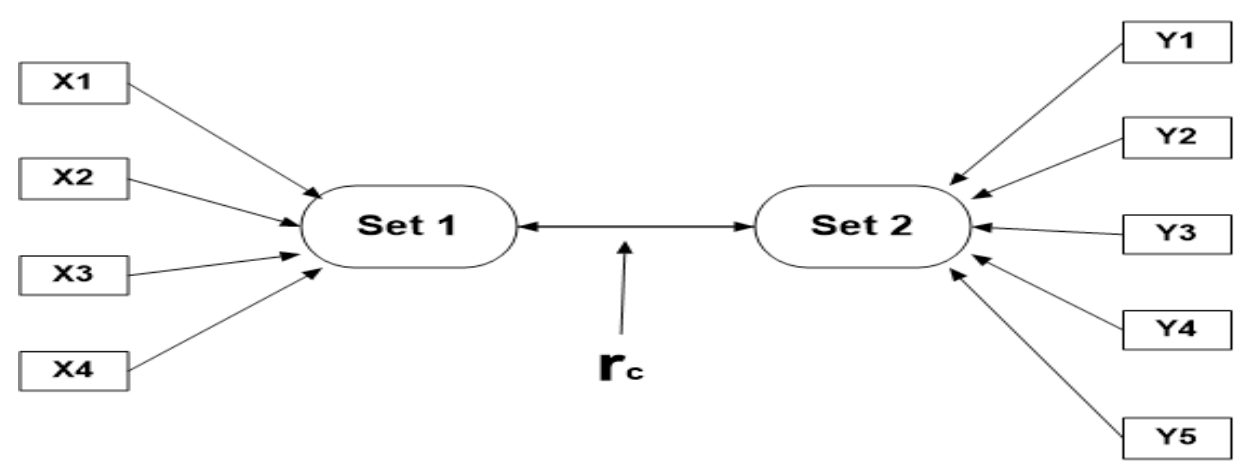

Figure 1. Illustration of the first function in a canonical correlation analysis with four predictors and five criterion variables. The canonical correlation is the simple Pearson $r$ between the two synthetic variables, which were linearly combined from the observed variables.

\section{Research Results}

Table 3 shows the correlation values of the sub-dimensions and descriptive values of the relation between the attitudes of the prospective teachers towards renewable energy sources and their critical thinking dispositions.

Table 3. Relation between renewable energy sources attitude and critical thinking disposition.

\begin{tabular}{|c|c|c|c|c|c|c|c|c|c|c|c|}
\hline Variables & Mean & $S D$ & 1 & 2 & 3 & 4 & 5 & 6 & 7 & 8 & 9 \\
\hline$A R(1)$ & 33.84 & 5.57 & 1 & & & & & & & & \\
\hline $\mathrm{IE}(2)$ & 24.44 & 3.80 & .72 & 1 & & & & & & & \\
\hline $\mathrm{Cl}(3)$ & 21.95 & 6.11 & .47 & .57 & 1 & & & & & & \\
\hline EAI (4) & 18.22 & 4.64 & .48 & .58 & .79 & 1 & & & & & \\
\hline MC (5) & 56.12 & 6.89 & .37 & .33 & .08 & .08 & 1 & & & & \\
\hline $\mathrm{FX}(6)$ & 43.91 & 5.88 & .32 & .31 & .10 & .08 & .79 & 1 & & & \\
\hline SYS (7) & 50.92 & 6.99 & .35 & .33 & .05 & .06 & .77 & .77 & 1 & & \\
\hline TP (8) & 30.86 & 5.05 & .27 & .23 & -.01 & -.02 & .59 & .58 & .68 & 1 & \\
\hline OM (9) & 11.92 & 2.02 & .26 & .25 & .04 & .06 & .48 & .58 & .58 & .54 & 1 \\
\hline
\end{tabular}

When the correlation values between the variables given in Table 3 were analysed, it was observed that the relation among the application request, importance of education, country interest, environmental awareness and investments in the first variable set changed between .47 and .79; the correlation coefficients of the relationships between the variables metacognition, flexibility, systematicity, tenacity-patience and open-mindedness in the second set of variables ranged between .79 and .48 . It was determined that the correlation coefficients between the first and the second variable sets changed between .37 and .02 .

In the canonical correlation analysis, multivariate significance test, which indicates whether the canonical model is statistically significant, was initially examined. These significance tests consist of four different tests: Pillais, Hotellings, Wilks, and Roys. Each of these tests can be converted to the $F$ test, so the significance of the canonical model resulting from the analysis can be tested. The theoretical basis for each of these four tests is different, which leads to a difference in the $F$ value calculated for each test. However, since it is generally more applicable in research, the comments were made based on the Wilks - test (Sherry \& Henson, 2005; Stevens, 2012). 
Table 4. Multivariate test of significance.

\begin{tabular}{cccccc}
\hline & Value & Approx $\boldsymbol{F}$ & Hypothesis $d f$ & Eror $d f$ & Significance of $\boldsymbol{F}$ \\
\hline Pillais & .22782 & 5.58058 & 20 & 1848 & $.000^{*}$ \\
Hotellings & .27878 & 6.37707 & 20 & 1830 & $.000^{*}$ \\
Wilks & .77770 & 5.99794 & 20 & 1523 & $.000^{*}$ \\
Roys & .20106 & & 20 & & \\
\hline
\end{tabular}

$\left(S=4, M=0, N=2281 / 2 ;{ }^{*} p<.0001\right)$

Table 4 shows that the canonical model obtained from the study was statistically significant [Wilks's $\lambda=.77770$, $F(20,1523)=5.998, p<.001]$. However, the significance of these tests does not give information about the strength of the relation obtained. In the canonical correlation analysis, it is important to make an assessment of the effect size as well as the significance of the model. In doing so, Wilks $\lambda$ value, which is called as reverse effect size, is used. Since Wilks $\lambda$ value expresses the unexplained variance between the canonical variables in the model obtained as a result of the analysis, " $1-\lambda$ " value gives the common variance amount shared by the canonical variables and is interpreted as $r^{2}$ value in the regression analysis. In this case, "1- $\lambda$ " value was calculated as 2223 for Wilks' $\lambda$ value obtained. According to this situation, it can be said that the common variance shared between the data sets of prospective teachers' attitudes towards renewable energy sources and their critical thinking dispositions is $22.23 \%$. After determining whether the canonical model is statistically significant, the significance of each canonical function in the model should be examined separately. Here, while the significance of the canonical model obtained from canonical correlation is tested, the cumulative values of the canonical functions are processed. In a canonical model where the cumulative values are statistically significant, while some of the canonical functions are significant, the relation between the variables may be very low. Therefore, while interpreting the results of canonical correlation analysis, the significance of each canonical function should be evaluated separately together with the canonical model. In order to determine which canonical functions are significant, eigenvalues of canonical functions and canonical correlation values are examined. In the research, as the result of the canonical correlation analysis used to review the relationship between the data sets of the attitude towards the renewable energy sources and the critical thinking disposition, four canonical functions were obtained. The eigenvalues and the canonical correlation values of these functions are shown in Table 5.

Table 5. Canonical correlation analysis results between renewable energy sources attitude and critical thinking disposition.

\begin{tabular}{cccccc}
\hline Roods & Eigenvalue & $\%$ & Cumulative $\%$ & $r_{c}$ & $r_{c}{ }^{2}$ \\
\hline 1 & .252 & 90.269 & 90.269 & .45 & .201 \\
2 & .018 & 6.343 & 96.612 & .13 & .017 \\
3 & .007 & 2.397 & 99.009 & .08 & .007 \\
4 & .003 & .991 & 100 & .05 & .003 \\
\hline
\end{tabular}

According to the findings in Table 5, the canonical correlation value for the first-order canonical function was found to be .45 . According to this, the data sets of the attitude towards renewable energy sources and critical thinking disposition in the first canonical function share a variance of $20.1 \%$. The canonical correlation value which was disregarded in the first canonical function and revealed the maximum relation between two canonical variables was calculated in the second order canonical correlation. It was determined that the canonical correlation value calculated for the second order canonical function was .13 and that the attitude towards the renewable energy sources and critical thinking disposition shared a variance of $1.7 \%$ in this function. After removing the common variance shared by the data sets in the first two canonical functions, it was seen that the canonical correlation value of the third canonical function was .08 and the common variance shared by the data sets for the third canonical function is .7\%. Finally, after removing the common variance shared by the data sets in the first three canonical functions, it was determined that the canonical correlation value of the fourth canonical function was .05 and the common variance shared by the attitude towards renewable energy sources and critical thinking disposition data 
sets for the third canonical function was .3\%. The analysis of the significance of each canonical function determined as the result of the analysis, also shed light on which functions that resulted from the canonical correlation analysis should be interpreted. Here, regarding which canonical functions should be interpreted as the result of the analysis, Tabachnick and Fidell (2007) stated it is appropriate to interpret only the statistically significant ones. Regarding which canonical functions should be interpreted, Sherry and Henson (2005) stated that the canonical value calculated for each function should be squared and the sum of the obtained values should be compared with the value of " $1-\lambda$ ". If the " $1-\lambda$ " value is equal to or greater than the value obtained in the comparison made here, that amount of function should be interpreted. The results of the dimension reduction analysis conducted for the relation between prospective teachers' attitude towards renewable energy sources and their critical thinking disposition datasets are given in Table 6.

Table 6. Dimension reduction analysis.

\begin{tabular}{cccccccc}
\hline Roods & Wilks L. & $\boldsymbol{F}$ & Hypothesis df & Eror $\boldsymbol{d} \boldsymbol{f}$ & $\mathbf{r}_{\mathrm{c}}$ & $\mathbf{r}_{\mathrm{c}}{ }^{2}$ & \multicolumn{2}{c}{ Significance of $\boldsymbol{F}$} \\
\hline 1 to 4 & .777 & 5.997 & 20 & 1523.28 & .448 & .201 & $.000^{*}$ \\
2 to 4 & .973 & 1.038 & 12 & 1217.34 & .132 & .017 & .410 \\
3 to 4 & .991 & .7253 & 6 & 922.00 & .081 & .007 & .629 \\
4 to 4 & .997 & .6383 & 2 & 462.00 & .052 & .003 & .529 \\
\hline
\end{tabular}

$(" p<.0001)$

When Table 6 is examined, for the first canonical model (function 1 to 4 ) regarding Wilk's $\lambda$ values and Chi-square values of four canonical functions obtained as a result of analysis, the canonical correlation coefficient calculated between the attitude towards renewable energy sources and critical thinking disposition is statistically significant [Wilks's $\lambda=.78, F(20,1523.28)=5.997, p<.001]$. The correlation value of the first canonical function was found to be .448. Accordingly, the shared variance between the data sets is $20.1 \%$. After removing the first canonical function where the correlation between the canonical variables was highest, it was determined that the relationship between the data sets for the remaining second canonical function (function 2 to 4 ) was not statistically significant [Wilks's $\lambda=.973, F(12,1217.34)=1.038, p>.05]$. According to the Wilks $\lambda$ value of this relationship, which consists of the cumulative values of the second, third and fourth canonical functions, the common variance shared between the data sets is $3 \%[" 1-\lambda "=.030]$. The relation between the data sets for the third canonical function (function 3 to 4) after the removal of the second canonical function was not statistically significant [Wilks's $\lambda=.991, F(6,922.00)$ $=.7253, p>.05]$. According to the Wilks $\lambda$ value of this relationship, which consists of the cumulative values of the third and fourth canonical functions, the common variance shared between the data sets is $0.9 \%$ ["1 $\left.1-\lambda^{\prime \prime}=.009\right]$. There was no statistically significant relationship between the data sets for the fourth canonical function (function 4 to 4 ) after the removal of the third canonical function [Wilks's $\lambda=.997, F(2,462.00)=.6383, p>.05$ ]. In this function, where the relation between canonical variables is the weakest, the data sets of the attitude toward the renewable energy sources and critical thinking disposition share only a . $3 \%$ common variance [" $1-\lambda "=.003]$.

To determine how application request (AR), importance of education (IE), country interest (CI) and environmental awareness and investments (EAI) variables in the data set of the attitudes toward renewable energy sources and metacognition (MC), flexibility (FX), systematicity (SYS), tenacity-patience (TP) and open-mindedness (OM) variables in the data set of critical thinking disposition contribute to the relation between the canonical variables, the standardized coefficients belonging to the first canonical function between the canonical variables and structural coefficients were researched. These obtained coefficients are given in Table 7.

In the presentation of the findings, the standardized coefficients of the canonical functions were shown as "Coef" and the structural coefficients as " $r_{s}$ ". In Table 7, while variables of application request (AR), importance of education (IE), country interest (CI) and environmental awareness and investments (EAI) are defined with the data set of the attitudes towards renewable energy sources, the common variance shared by these variables with the data set of critical thinking disposition is shown as " $r_{c}{ }_{c}$ "In addition, it is stated in the same table, by summing $r_{c}^{2}$ values in the first canonical function of $A R, I E, C l$ and EAI variables included in the data set of the attitudes towards renewable energy sources and MC, FX, SYS, TP and OM variables in the data set of critical thinking disposition, what is the common variance shared by these variables with the data set in the canonical model. In order to determine whether the variables they share with the data set are important or not, the value of .45 is taken as the criterion. 
Accordingly, it can be said that the contribution of the variables with the $r_{s}$ values .45 or above to their data sets are important (Sherry, \& Henson, 2005). In order for the variables in each data set to be a part of the canonical model, their correlation should be greater than .30 (Tabachnick and Fidell, 2007).

Table 7. Canonical solution for renewable energy sources attitude and critical thinking disposition for functions 1.

Function 1

\begin{tabular}{|c|c|c|c|}
\hline Variables & Coef. & $r_{s}$ & $r_{s}^{2}(\%)$ \\
\hline$A R$ & -.706 & -.86 & .74 \\
\hline IE & -.621 & -.77 & .60 \\
\hline $\mathrm{Cl}$ & .292 & -.13 & .02 \\
\hline EAl & .329 & -.14 & .02 \\
\hline \multicolumn{2}{|c|}{$r_{c}^{2}$} & \multicolumn{2}{|c|}{20.1} \\
\hline$M C$ & -.512 & -.92 & .85 \\
\hline FX & .094 & -.81 & .65 \\
\hline SYS & -.388 & -.92 & .85 \\
\hline $\mathrm{TP}$ & -.156 & -.77 & .60 \\
\hline $\mathrm{OM}$ & -.184 & -.69 & .47 \\
\hline
\end{tabular}

Structure coefficients ( $r$ s) greater than $|.45|$ are underlined. Coef $=$ standardized canonical function coefficient; $r$ s = structure coefficient; = squared structure coefficient

When Table 7 is examined, it is determined that the contribution of AR and IE variables to the data set of the attitudes towards renewable energy sources is over .45 in the first canonical function. The structural coefficient of the $\mathrm{Cl}$ and EAI variables was found to be below .45. Accordingly, it can be said that the contribution of AR and IE variables for the first canonical function to the data set of the attitudes towards renewable energy sources is more important than the $\mathrm{Cl}$ and EAI variables. Similarly, the contribution of MC, FX, SYS, TP and OM variables in the first canonical function to the critical thinking disposition data set is over .45. Thus, it can be said that the contribution of MC, FX, SYS, TP and OM variables in the first canonical function to the critical thinking disposition data set is important.

In canonical functions obtained from canonical correlation analysis, the direction of the relation among these variables can be determined depending on the positivity or negativity of variables which have a significant contribution to the data set (having a structural coefficient of .45 or more). In the first canonical function where the coefficients of AR and IE variables are significant, when the signs of variables are examined it is seen that the variables are negative. According to this, it can be said that there is a same-directional relationship between AR and IE variables. When the variables of critical thinking disposition data set in first canonical function are examined; MC, FX, SYS, TP, and $O M$ all have negative signs and a same-directional relation. According to Table 7; there is a positive-directional relation between AR and El variables and MC, FX, SYS, TP and OM variables. According to this result; as the attitude towards renewable energy sources in terms of the application request (AR) and the importance of education (IE) increases, the metacognitive (MC), their flexibility (FX), their systematicity (SYS), their tenacity and patience (TP), and their open mindedness (OM) among critical thinking dispositions increase. According to Table $7, r_{c}^{2} v a l u e$ for the first canonical function was calculated as 20.01. This value reveals that the common variance shared between the data sets of attitudes towards the renewable energy sources and the critical thinking disposition in the first canonical function is $20.1 \%$. In addition, the canonical correlation coefficients between the structural coefficients of the first canonical function and the data sets for this function are given in Figure 2. 


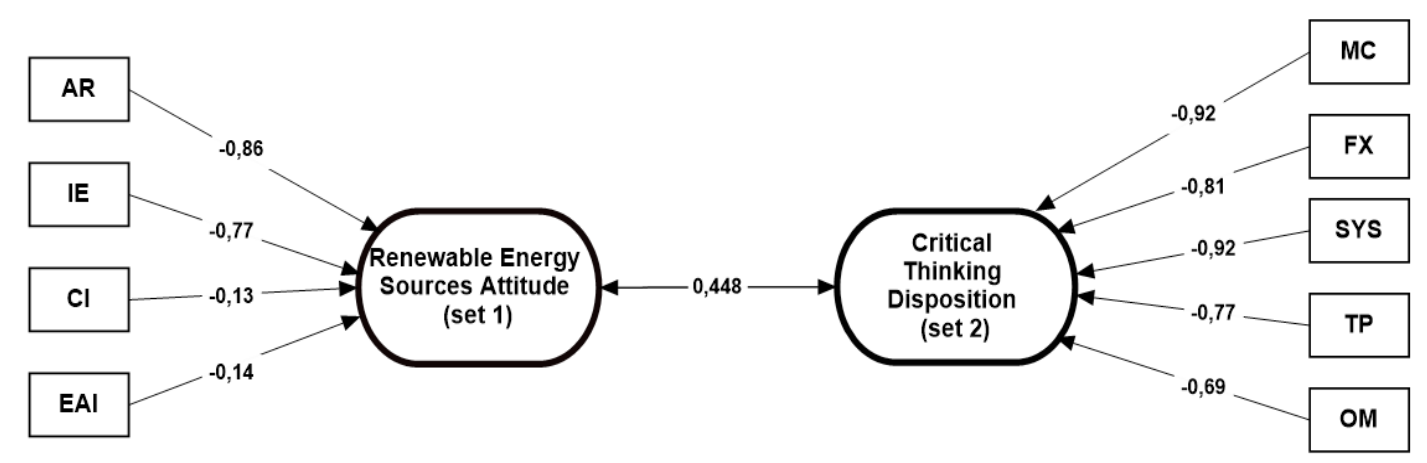

Figure 2. Canonical correlation results.

As a result, according to the data obtained from the participants, it was determined that the common variance shared by the data sets of the attitude towards renewable energy sources and the critical thinking disposition was $22.23 \%$. Based on the findings obtained from the canonical correlation analysis, the relation between attitude towards renewable energy sources and critical thinking disposition is given in Figure 3.

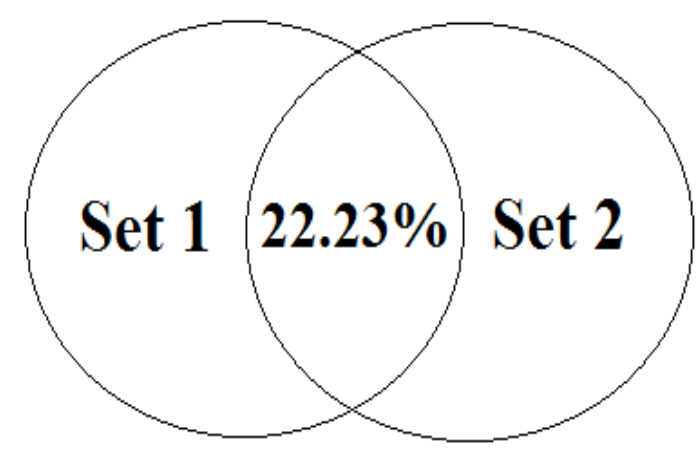

Figure 3. The shared common variance by two data sets (22.23\%).

\section{Discussion}

This research was carried out to reveal the relation between prospective teachers' attitudes towards renewable energy sources and critical thinking dispositions.

Correlation analysis was performed to determine the relationship between the sub-dimensions of the scales. As a result of the analysis, firstly, the application request, one of the sub-dimensions of the scale of the attitude towards renewable energy sources, has found to have a low-level positive relation with metacognition, flexibility, systematicity and tenacity-patience among the sub-dimensions of the scale for critical thinking dispositions. According to this result, the request of prospective teachers to have detailed knowledge about renewable energy resources, their desire to attend scientific meetings and to prepare projects was observed to be related to their awareness of their own cognitions, thinking flexibly, controlling their thoughts and acts in a planned manner, and being confident against the barriers for the problems. When the literature is examined, it is seen that the prospective teachers are willing for applications for renewable energy sources (Bilen, Ozel, \& Surucu, 2013; Cebesoy \& Karisan, 2017; Karabulut \& Alkan, 2010). In these studies, prospective teachers stated that they were willing to use and apply these resources due to the reasons such as the fact that renewable energy sources do not harm the environment, there is no danger of exhaustion like fossil fuels and the cost of plant installation is low. In addition, 
prospective teachers stated that renewable energy sources can be used for water heating and supplying energy for electronic equipment in houses and they are willing to implement these systems (Cebesoy \& Karisan, 2017). In this direction, it can be said that metacognition, flexible thinking, systematicity and tenacity are important factors in increasing the requests of prospective teachers. As a result of the analysis, secondly, the importance of education, one of the sub-dimension of the scale of the attitude towards the renewable energy sources, was determined to have a low-level positive relation with metacognition, flexibility, systematicity and tenacity-patience, the sub-dimensions of the scale of the critical thinking dispositions. According to this result, it can be seen that seeing the education as an important factor to use renewable energy sources properly and effectively, to provide energy saving and get habits of saving has relationship with prospective teachers' reflection of their thinking process, their ability to think on this reflection, to act in a planned and organized manner by thinking distinctively for the issues and questions and to be persistent in case of failures. Liarakou, Gavrilakis and Flouri (2009) reported that education plays an important role in informing about renewable energy sources, raising educated individuals and raising their awareness. In this context, it can be said that metacognition, flexible thinking, systematicity and tenacity are important factors in providing an awareness that education is important for prospective teachers to have sufficient knowledge about renewable energy sources. As a result of the analysis, lastly, it was determined that the country interest, which is the sub-dimension of the scale of the attitude towards renewable energy resources had a low-level positive relationship with flexibility, which is the sub-dimension of the scale of the critical thinking dispositions. According to this result, it was seen that the thoughts of prospective teachers that the use of renewable energy sources would increase the development level of the country, contribute to the economy of the country and would be beneficial for development, had a relationship with the ability of prospective teachers to develop different points of view for the different encounters and to think distinctively. In the literature on this, it has been stated that countries have started to prefer renewable energy sources in their energy policies, and they are in search of different energy sources (Karabulut \& Alkan, 2010). Prospective teachers have thought that the use of renewable energy sources will contribute to the country's economy, create job opportunities, increase regional development and reduce dependence on foreign countries (Cebesoy \& Karisan, 2017). In this respect, it can be said that flexible thinking and country interest are important factors in increasing the attitudes of prospective teachers towards renewable energy resources.

As a result of the canonical correlation analysis conducted in the study, four canonical functions related to the relationship between participants' attitudes towards renewable energy sources and critical thinking dispositions were obtained. Only one canonical function was found to be statistically significant among these functions. It has been determined that the data sets of attitude towards renewable energy sources and critical thinking disposition in the first canonical function, which is calculated in order to maximize the relation between the attitudes towards renewable energy sources and the critical thinking disposition data sets, share a variance of $20.1 \%$. In the second canonical function, the canonical correlation value, which is not taken into account in the first canonical function and reveals the maximum relation between the two canonical variables, is calculated. In the second canonical function, the common variance shared by the attitudes towards the renewable energy sources and the critical thinking disposition data sets was found to be $1.7 \%$. After removing the common variance shared by the data sets in the first two canonical functions, the common variance shared by the attitude and critical thinking disposition data sets for the third canonical function was .7\%. Similarly, after removing the common variance shared by the first three canonical functions, it was determined that the common variance shared by the attitude and critical thinking disposition data sets for the fourth canonical function was . $3 \%$.

In the canonical model consisting of the cumulative values of the canonical functions obtained from the canonical correlation analysis, the common variance shared by the data sets of critical thinking disposition and attitudes towards renewable energy sources was calculated as $22.23 \%$. This result shows that there is a relation between the prospective teachers' attitudes towards renewable energy sources and their critical thinking. Studies on this also indicate that the critical thinking of individuals can affect their thoughts, evaluations, decisions and attitudes towards renewable energy sources (Lee, 2016; Opitz, 2016; Sakschewski, Eggert, Schneider, \& Bogeholz, 2014). In this context, the fact that prospective teachers are aware of what he/she should do in order to solve many environmental problems related to energy such as global warming, acid rain, climate change, disaster and migration, and what environmental impacts might be in case anything is not done, in a sense, their awareness of their own metacognition may have positively affected their attitudes towards renewable energy sources. In addition, it can be effective to reveal this kind of relationship that prospective teachers learn the scientific information about 
the sources in the classes about the renewable energy sources in the teachers' training programs, have estimations for their environmental effects, associate the important connections and see the different thoughts by discussing. In addition, prospective teachers' ability to establish relation between different perspectives on environmental problems in the courses related to renewable energy resources, and to seek answers to the problems in a multifaceted and conscious manner, and thus to carry out critical thinking in the classes, may also increase attitudes towards these sources.

\section{Conclusion and Implications}

As a result of this research, it was seen that critical thinking disposition such as metacognition, flexibility, systematicity, tenacity-patience, and open-mindedness were effective in increasing the attitudes of the future teachers towards renewable energy sources. Considering that it is important for the future students to bring sensitivity and solution suggestions to environmental problems in line with the changes and developments in the world, the importance of critical thinking skill which is one of the 21st century skills is emphasized with this research.

In line with the results of the study, critical thinking in teaching activities should be carried out in relation to environmental factors in these courses related to renewable energy resources in teacher training programs. In addition, these courses can be done about the renewable energy resources and their investments in the country's economy, regional development and interaction with the environment and it should be provided that prospective teachers think critically. In addition, it is recommended to search the factors that direct the attitudes towards renewable energy sources and critical thinking dispositions of the prospective teachers. Qualitative studies can also be conducted for in-depth study of the relationships obtained in this study. In this context, it can be suggested to conduct new researches to examine the relationship between the attitudes towards renewable energy sources and critical thinking dispositions by using different data collection techniques such as interview and observation. Thus, more detailed information about the relation between attitudes towards renewable energy sources and critical thinking dispositions can be obtained.

\section{References}

Akar, C. (2007). Critical thinking of elementary school students. Unpublished PhD Dissertation. Gazi University Institute of Educational Sciences, Ankara.

Alper, A. (2010). Critical thinking disposition of pre-service teachers. Education and Science, 35(158), 14-27.

Apergis, N., \& Payne, J.E. (2010). Renewable energy consumption and economic growth: Evidence from a panel of OECD countries. Energy Policy, 38, 656-660.

Argon, T., \& Selvi, C. (2011). Öğretmen adaylarının eleştirel düşünme eğilimleri ve çatışma yönetim stilleri (Prospective teachers' critical thinking dispositions and conflict management styles). Journal of Educational and Instructional Studies in the World, 1(1), 93-100.

Balocco, C., \& Grazzini G. (2007). Plant refurbishment in historical buildings turned into museum. Energy and Buildings, 39(6), 693-701.

Baris, K., \& Kucukali, S. (2012). Availability of renewable energy sources in Turkey: Current situation, potential, government policies and the EU perspective. Energy Policy, 42, 377-391.

Bayrac, H.N. (2010). Effects of energy use on global warming and prevention policies. Eskisehir Osmangazi University Journal of Social Sciences, 11(2), 229-260.

Benli, H. (2013). Potential of renewable energy in electrical energy production and sustainable energy development of Turkey: Performance and policies. Renewable Energy, 50, 33-46.

Besoluk, S., \& Onder, l. (2010). Investigation of teacher candidates' learning approaches, learning styles and critical thinking dispositions. Elementary Education Online, 9(2), 679-693.

Bilen, K., Ozel, M., \& Surucu, A. (2013). Pre-service science teachers' awareness about renewable energy. Dumlupinar University Journal of Social Sciences, 36, 102-118.

Bordens, K. S., \& Abbott, B. A. (2011). A process approach to research design and methods. New York: McGraw-Hill.

Can, S., \& Kaymakci, G. (2015). Pre-service teachers' critical thinking tendencies. Education Sciences, 10(2), 66-83.

Cebesoy, U. B., \& Karisan, D. (2017). Investigation of preservice science teachers'knowledge, teaching efficacy perceptions and attitude towards renewable energy sources. Van Yuzuncu Yil University Journal of Education, 14(1), 1377-1415. doi: 10.23891/efdyyu.2017.49.

Cekic, S. (2007). The analysis of the power of mathematics teaching degree students on the basis of certain variables. Unpublished master thesis. Dokuz Eylul University Institute of Social Sciences, İzmir.

Celikler, D. (2013). Awareness about renewable energy of pre-service science teachers in Turkey. Renewable Energy, 60 , 343-348. https://doi.org/10.1016/j.renene.2013.05.034. 
ISSN 1648-3898/Print/ THE RELATION BETWEEN TEACHERS' ATTITUDES TIWARDS RENEWABLE ENERGY SLURCES

Cetin, A. (2008). The critical thinking ability of the pre-service teachers. Unpublished master thesis. Uludag University Institute of Social Sciences, Bursa.

Cohen, J. (1968). Multiple regression as a general data-analytic system. Psychological Bulletin, 70, 426-433.

Coker, B., Catlioglu, H. \& Birgin, O. (2010). Conceptions of students about renewable energy sources: A need to teach based on contextual approaches. Procedia-Social and Behavioral Sciences, 2, 1488-1492.

Colwill, I., \& Gallagher, C. (2007). Developing a curriculum for the twenty-first century: The experiences of England and Northern Ireland. Prospects, 37(4), 411-425.

Craft, A. (2003). School and critical thinking. Teaching of Psychology, 30(3), 220-224.

Dayioglu, S. (2003). A descriptive study on the critical thinking levels of the students at the unit of English preparatory school at Hacettepe University. Unpublished master thesis. Middle East Technical University Institute of Social Sciences, Ankara.

Dincer, I. (1998). Energy and environmental impacts: Present and future perspectives. Energy Sources, 20(4), 427-53.

Dogan, N. (2014). The role of renewable energy resources in fighting against global climate change: An assessment for Turkey. IIB International Refereed Academic Social Sciences Journal, 5(15), 265-276.

Emir, S. (2012). Eğitim fakültesi öğrencilerinin eleştirel düşünme eğilimleri [Critical thinking dispositions of faculty students]. HAYEF Journal of Education, 9(1), 34-57.

Ennis, R. (1985). Goals for critical thinking curriculum. A. Costa (Ed.), Developing minds. (pp. 54-57). Alexandria, VA: Association for Supervision and Curriculum Development.

Erdem, M., llgan, A., \& Celik, F. (2013). Relationship between emotional intelligence and critical thinking skills of high school teachers. Turkish Studies, 8(12), 509-532.

Firat, A., Sepetcioglu, H., \& Kiraz, A. (2012). Analysis of the attitudes of teacher candidates about renewable energies. Hacettepe University Journal of Education, Special 1, 216-224.

Fraenkel, J. R., \& Wallen, N. E. (2006). How to design and evaluate research in education (6th ed.). New York: McGraw Hill.

Girot, E. A. (2000). Graduate nurses: Critical thinkers or better decision makers? Journal of Advanced Nursing, 31(2), 288-297.

Gulveren, H. (2007) Critical thinking skills of education faculty students and factors influencing critical thinking skills. Unpublished PhD Dissertation. Dokuz Eylul University Institute of Educational Sciencies, İzmir.

Guner, E. D., \& Turan, E.S. (2017). The impact of renewable energy sources on global climate change. Journal of Natural Hazards and Environment, 3(1), 48-55.

Guven, G., \& Sulun, Y. (2017). Pre-service teachers' knowledge and awareness about renewable energy. Renewable and Sustainable Energy Reviews, 80, 663-668.

Guven, M., \& Kurum, D. (2008). The relationship between teacher candidates' learning styles and critical thinking dispositions. Elementary Education Online, 7(1), 53-70.

Gunes, T., Alat, K., \& Gozum, A.I.C. (2013). Renewable for science teacher candidates enegy sources attitude scale: Validity and reliability study. Journal of Educational Sciences Research, 3 (2), 269-289.

Halder, P., Nuutinen, S., Pietarinen, J., \& Pelkonen, P. (2011). Bioenergy and the youth: Analyzing the role of school, home, and media from future policy perspectives. Applied Energy, 88 (4), 1233-1240.

Halder, P., Pietarinen, J., Havu-Nuutinen, S., \& Pelkonen, P. (2010). Young citizens' knowledge and perceptions of bioenergy and future energy implications. Energy Policy, 38, 3058-3066.

Haskok, A. S. (2005). The assessment of Turkey`s present energy resources. Unpublished master thesis. Eskisehir Osmangazi University Graduate School of Natural and Applied Sciences, Eskişehir.

Henson, R. K. (2002, April). The logic and interpretation of structure coefficients in multivariate general linear model analyses. Paper presented at the Annual Meeting of the American Educational Research Association, New Orleans.

Irani, T., Rudd, R., Gallo, M., Ricketts, J., Friedel, C., \& Rhoades, E. (2007). Critical thinking instrumentation manual. Retrieved from http://step.ufl.edu/resources/critical_thinking/ctmanual.pdf.

Islamoglu, H.A. (2003). Scientific research method. İstanbul: Beta Yayınları.

Jatmiko, B., Prahani, B.K., Supardi, Z.A., Wicaksono, I., Erlina, N., Pandiangan, P., \& Althaf, R. (2018). The comparison of oripa teaching model and problem-based learning model effectiveness to improve critical thinking skills of pre-service physics teachers. Journal of Baltic Science Education, 17(2), 300-319.

Karabulut, A., \& Alkan, M.A. (2010). An empirical study investigating the teaching of renewable energy sources which are important in the global financial crisis environment at university level. What others manifest. World Econ Theory Turbul Global Finance Crisis, 420-427.

Karakas, A. (2014). The relationship between electricity consumption, population and income in OECD and non-OECD countries: A panel date analysis for 1990-2011 period. Turkish Studies, 9(2), 845-853.

Karasar, N. (2016). Scientific research method. Ankara: Nobel Yayın Dağıtım.

Karatepe, Y., Varbak, N., Kecebas, A., \& Yumurtaci, M. (2012). The levels of awareness about the renewable energy sources of university students in Turkey. Renewable Energy, 44, 174-179.

Kilinc, A., Stanisstreet, M., \& Boyes, E. (2009). Incentives and disincentives for using renewable energy: Turkish students' ideas. Renewable and Sustainable Energy Reviews, 13(5), 1089-1095.

Knapp, T.R. (1978). Canonical correlation analysis: A general parametric significance-testing system. Psychological Bulletin, $85,410-416$.

Koca, N., \& Bulut, R. (2015). Opinions of prospective social studies teachers about energy resources of Turkey. Turkish Studies, 10(11), 1007-1022. 
Kocak, B., Kurtlu, Y., Ulas, H., \& Epcacan, C. (2015). Examining of the elementary class teachers' critical thinking levels and their attitudes towards reading. EKEV Academy Journal, 19(61), 211-228.

Kokdemir, D. (2003). Decision making and problem solving under uncertainty. Unpublished PhD Dissertation. Ankara University Institute of Social Sciencies, Ankara.

Komor, P., \& Bazilian, M. (2005). Renewable energy policy goals, programs, and technologies. Energy Policy, 33, 1873-1881.

Korkmaz, O. (2009a). Teachers' critical thinking level and dispositions. Journal of Kirsehir Education Faculty, 10(1), 1-13.

Korkmaz, O. (2009b). The influence of education faculties on students' critical thinking level and disposition. The Journal of Turkish Educational Sciences, 7(4), 879-902.

Koroneos, C., Spachos, T., \& Moussiopoulos, N. (2003). Energy analysis of renewable energy sources. Renewable Energy, 28(2), 295-310.

Krohn, S., \& Damborg, S. (1999). On public attitudes towards wind power. Renewable Energy, 16, 954-960.

Kurum, D. (2002). Critical thinking abilities of teacher trainees. Unpublished master thesis. Anadolu University Institute of Educational Sciences, Eskişehir.

Lee, P.L. (2016). Misconceptions and biases in German students' perception of multiple energy sources: Implications for science education. International Journal of Science Education, 38(6), 1306-1056.

Liarakou, G., Gavrilakis, C., \& Flouri, E. (2009). Secondary school teachers' knowledge and attitudes towards renewable energy sources. Journal of Science Education and Technology, 18(2), 120-129.

Norris, S.P. (1985). Synthesis of research on critical thinking. Educational Leadership, 8, 40- 45.

Opitz, S. (2016). Students' progressing understanding of the energy concept: an analysis of learning in biological and crossdisciplinary contexts. Unpublished PhD Dissertation Thesis. Christian-Albrechts Universität Kiel.

Ozdemir, S.M. (2005). Assessing university students' critical thinking skills for some variables. The Journal of Turkish Educational Sciences, 3(3), 1-17.

Rudd, R.D. (2007). Defining critical thinking. Techniques: Connecting Education and Careers, 82(7), 46-49.

Sacli, F., \& Demirhan, G. (2008). A determination and comparison of critical thinking levels of students in physical education teacher training program. Hacettepe Journal of Sport Sciences, 19(2), 92-110.

Sakschewski, M., Eggert, S., Schneider, S., \& Bogeholz, S. (2014). Students' socioscientific reasoning and decision-making on energy-related issues-development of a measurement instrument. International Journal of Science Education, 36(14), 2291-2313.

Sarac, E., \& Bedir, H. (2014). Primary school teachers related to perceptions of renewable energy sources on the qualitative research. Science Journal of Turkish Military Academy, 24(1), 19-45.

Seferoglu, S.S., \& Akbiyik, C. (2006). Teaching critical thinking. Hacettepe University Journal of Education, 30, $193-200$.

Semerci, N. (2016). The development of critical thinking disposition scale (CTHD): Study on the revision of validity and reliability. Turkish Studies, 11(9), 725-2740.

Sen, U. (2009). An evaluation about Turkish teacher candidates' critical thinking attitude's in terms of difference variable. Zeitschrift für die Welt der Türken Journal of World of Turks, 1(2), 69-89.

Senlik, N.Z., Balkan, O., \& Aycan, S. (2011). Critical thinking dispositions of pre-service teacher: Mugla University example. C.B.U. Journal of Science, 7(1), 67-76.

Sherry, A., \& Henson, R. K. (2005). Conducting and interpreting canonical correlation analysis in personality research: A user-friendly primer. Journal of Personality Assessment, 84, 37-48.

Stevens, J.P. (2012). Applied multivariate statistics for the social sciences. New York: Routledge.

Tabachnick, B.G., \& Fidell, L.S. (2007). Using multivariate statistics (5th ed.). Boston: Allyn and Bacon.

Tas, A.M. (2004). Determination of curriculum standards of social studies teaching. Ankara University Journal of Faculty of Educational Sciences, 37(1), 28-54.

Tasci, S. (2005). The problem-solving process in nursing. Journal of Health Sciences, 14, 73-78.

Thompson, B. (1991). A primer on the logic and use of canonical correlation analysis. Measurement and Evaluation in Counseling and Development, 24, 80-95.

Tishman, S., Jay, E., \& Perkins, D.N. (1993). Teaching thinking dispositions: From transmission to enculturation. Theory into Practice, 32(3), 147-153.

Turnuklu, E.B., \& Yesildere, S. (2005). A profile from Turkey: Critical thinking dispositions and abilities of pre-service mathematics teachers of 11-13 year. Ankara University Journal of Faculty of Educational Sciences, 38(2), 167-185.

Walsh, C.M., \& Hardy, R.C. (1999). Dispositional differences in critical thinking related to gender and academic major. Journal of Nursing Education, 38(4), 149-155.

Wolsing, M. (2007). Wind power implementation: the nature of public attitudes: Equity and fairness instead of 'backyard motives'. Renewable \& Sustainable Energy Reviews, 11(6), 1188-1207.

Yaman, S., \& Yalcin, N. (2005). Effectiveness on creative thinking skills of problem-based learning approach in science teaching. Elementary Education Online, 4(1), 42-52.

Yanpar Yelken, T. (2009). The effects of materials development based on "creativity activities within a group" on teacher candidates' portfolios. Education and Science, 34(153), 83-98.

Yazicioglu, Y., \& Erdogan, S. (2014). SPSS uygulamalı bilimsel araltırma yöntemleri [SPSS applied scientific research methods]. Ankara, Detay Yayıncılık. 
Yuenyong, C., Jones, A., \& Yutakom, N. (2008). A comparison of Thailand and New Zealand students' ideas about energy related to technological and societal issues. International Journal of Science and Mathematics Education, 6, 293-311.

Yuksel, I., \& Kaygusuz, K. (2011). Renewable energy sources for clean and sustainable energy policies in Turkey. Renewable and Sustainable Energy Reviews, 15, 4132-4144.

Zayif, K. (2008). Critical thinking dispositions of teachers canditates. Unpublished master thesis. Abant Izzet Baysal University Institute of Social Sciences, Bolu.

Zhang, L.F. (2003). Contributions of thinking styles to critical thinking dispositions. Journal of Psychology, 137(6), 517-543.

Zyadin, A., Puhakka, A., Ahponen, P., Cronberg, T, \& Pelkonen, P. (2012). School students' knowledge, perceptions, and attitudes toward renewable energy in Jordan. Renewable Energy, 45, 78-85.

Gokhan Guven (Corresponding author)

Nevin Kozcu Cakir
Dr., Research Assistant in Department of Maths and Science Education in Mugla Sitki Kocman University, Turkey. E-mail: gokhanguven@mu.edu.tr

Dr., Research Assistant in Department of Maths and Science Education in Mugla Sitki Kocman University, Turkey.

E-mail: nkozcu@mu.edu.tr 